\title{
LCK wt Allele
}

National Cancer Institute

\section{Source}

National Cancer Institute. LCK wt Allele. NCI Thesaurus. Code C51119.

Human LCK wild-type allele is located in the vicinity of $1 \mathrm{p} 34.3$ and is approximately $35 \mathrm{~kb}$ in length. This allele, which encodes proto-oncogene tyrosine-protein kinase LCK protein, plays a role in T-cell antigen receptor-linked signal transduction pathways. The LCK gene is associated with acute lymphoblastic leukemia and severe combined immunodeficiency. 